\title{
An extreme extra-limital record of a strap-toothed beaked whale Mesoplodon layardii from the northern Indian Ocean in Myanmar
}

\author{
AUNG MYO CHIT ${ }^{1}$, BRIAN D. SMITH ${ }^{2}$ AND MYA THAN TUN ${ }^{3}$ \\ ${ }^{1}$ Myanmar Program, Wildlife Conservation Society, Aye Yeik Mon, Hlaing Township, Yangon 11051, Myanmar, ${ }^{2}$ Ocean Giants \\ Program, Wildlife Conservation Society, 2300 Southern Boulevard, Bronx, New York 10460, USA, ${ }^{3}$ Environment and Endangered \\ Aquatic Animal Conservation Unit, Department of Fisheries, B.P.I. Road, West Gygon, Insein, Yangon, Myanmar
}

\begin{abstract}
On 29 February 2011 a strap-toothed beaked whale Mesoplodon layardii stranded in the mouth of the Pyin Sa Lu and Thaung Du rivers bordering the northern Indian Ocean in Myanmar at approximately $16^{\circ} \mathrm{N}$ of the equator. This stranding occurred more than $5000 \mathrm{~km}$ from the normal distribution of the species in cold temperate waters below $35^{\circ} \mathrm{S}$. Mesoplodonts are the most poorly known of all cetaceans; however, due to the large number of documented strandings and the species' distinctive appearance, the distribution of strap-toothed beaked whales is probably the best known of the genus. For these reasons, the Myanmar stranding is believed to be an anomalous extra-limital occurrence rather than an extension of the species' normal distribution.
\end{abstract}

Keywords: beaked whales, cetaceans, extra-limital record, Mesoplodon, stranding, strap-toothed, Myanmar

Submitted 25 October 2011; accepted 4 November 2011

\section{INTRODUCTION}

Beaked whales from the Mesoplodon genus are among the most poorly known mammal groups. This is due to their occurrence in deep ocean waters and the difficulties of distinguishing between species during the relatively brief periods of time they spend on the water surface. As the diagnostic features of these animals have become better known, information has increasingly become available from at-sea sightings (e.g. Carlström et al., 1997; Pitman \& Lynn, 2001). However, most knowledge about these whales still comes from strandings.

\section{METHODS AND RESULTS}

On 29 January 2011, at approximately 0630, the Department of Fisheries (DoF), Myanmar, received a report that a whale had stranded alive on a sandy beach in the mouth of the Pyin Sa Lu and Thaung Du rivers in the Ayeyarwady Delta of Myanmar $\left(15^{\circ} 47^{\prime} 35^{\prime \prime} \mathrm{N} 94^{\circ} 50^{\prime} 15^{\prime \prime} \mathrm{S}\right.$ ) (Figure 1). Before the DoF officers arrived, local army personnel reported that they attempted to drag the whale back to sea using a rope wrapped around its tail stock and a motorized boat, but they gave up the attempt after the animal vocalized a call they said sounded like a squealing pig. They interpreted

Corresponding author:

B.D. Smith

Email: bsmith@wcs.org this call as indicating pain. The local villagers then manually supported the whale in shallow water until it died at around 1600 on the same day.

From photographs taken by DoF officers, and based on its large size, spindle shaped body, long rostrum, complex colour pattern of sharply contrasting white and dark-grey patches, and tusks that emerge from the middle of the lower jaw extending backwards at $\sim 45^{\circ}$ angle and over the top of the upper jaw, the animal was identified as an adult male strap-toothed beaked whale Mesoplodon layardii (Figure 2; see Jefferson et al., 2008). The overall body condition of the animal was good and the laceration visible in Figure 2 was reportedly caused during the stranding when the army personnel attempted to drag the animal back to sea. After the animal died, the DoF officers took non-standardized measurements (curved length, 17 feet (5.2 m); girth, 9 feet $(2.7 \mathrm{~m})$; dorsal fin height, 1.4 feet $(0.4 \mathrm{~m})$; fluke width, 4.5 feet $(1.4 \mathrm{~m})$; pectoral fin length, 2.0 feet $(0.6 \mathrm{~m})$; and tusk length, 0.5 feet $(0.2 \mathrm{~m})$ ). They cut open the stomach, which they found to be empty, and flensed the skin, muscle and blubber off the skeleton. The skull was collected and taken to Yangon for further study and the remainder of the skeleton was buried at the Pyin Sa Lu DoF office to be dug up later for display.

\section{DISCUSSIDN}

The strap-toothed beak whale is one of the better known mesoplodonts due to its apparent propensity to strand more often than other species in the genus. Its distinctive colour pattern and the visible tusks of adult males also make the 


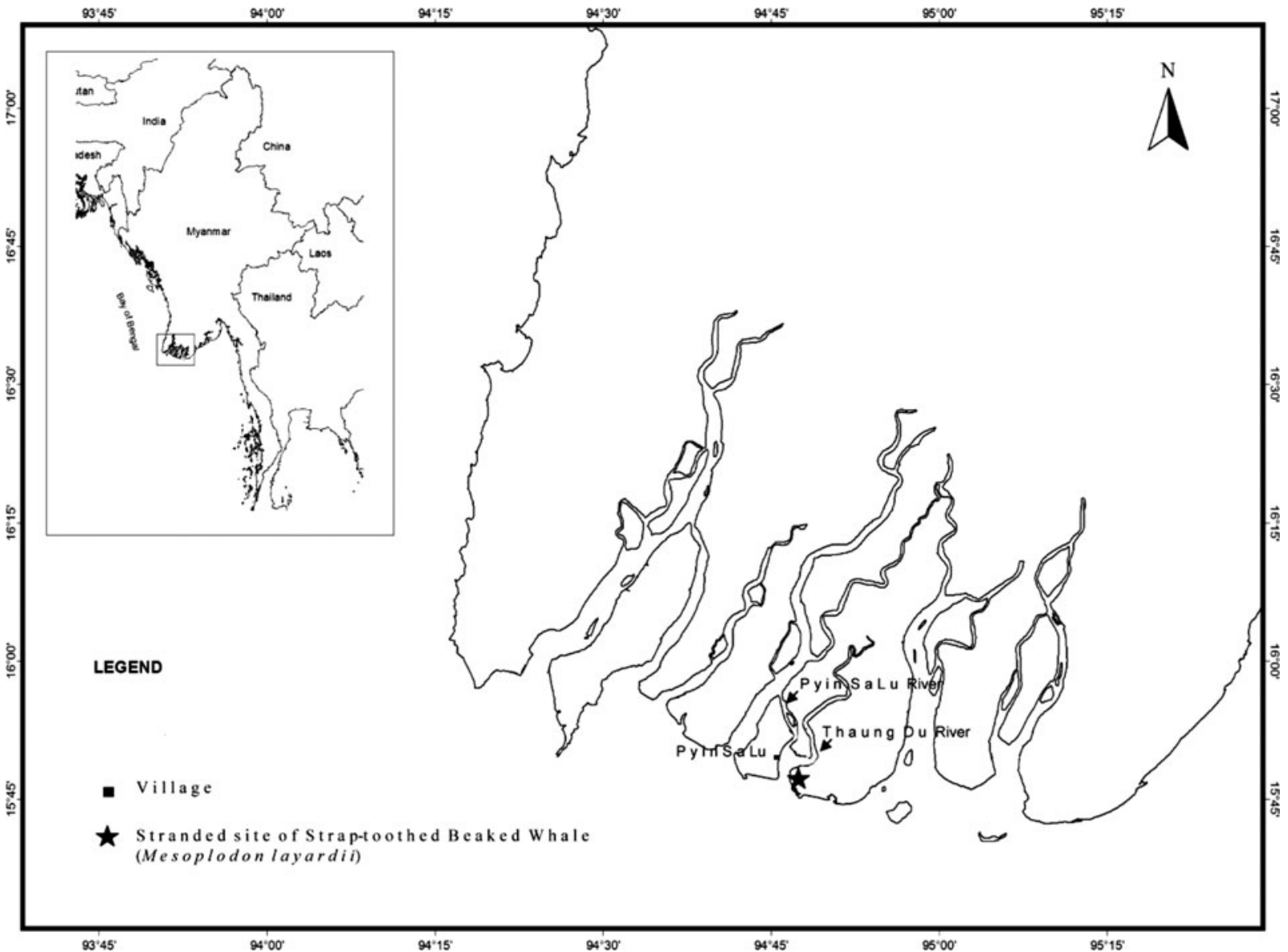

Fig. 1. Map of the Ayeyarwady Delta showing the mouths of the Pyin Sa Lu and Thaung Du rivers, and an inset map of Myanmar and adjacent countries.

species fairly easy to identify at sea (Jefferson et al., 2008). The bizarre configuration of the tusks in adult males prevents them from opening their mouths more than a few centimetres and limits their diet to small squid and occasional small fish and crustaceans (Sekiguchi et al., 1996).

Strap-toothed whales have been described as having a circumglobal distribution in cold temperate and sub-Antarctic

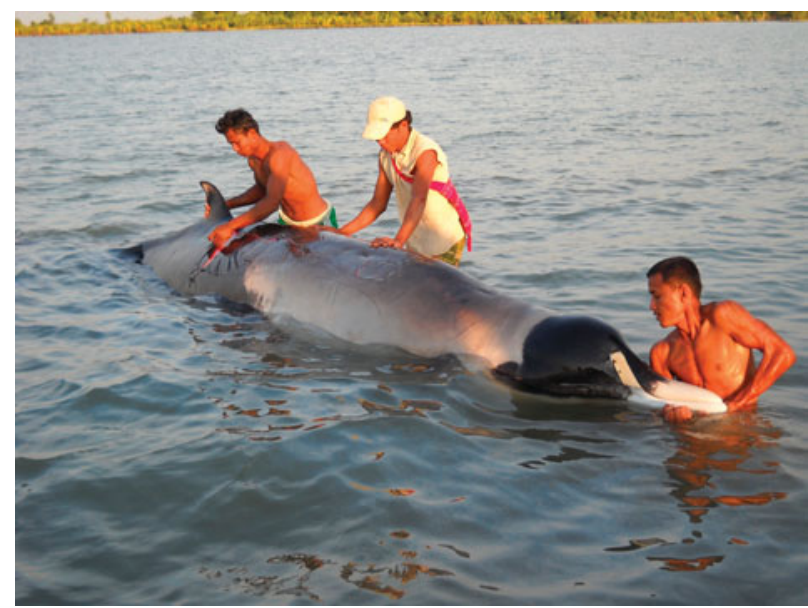

Fig. 2. Adult male strap-toothed beaked whale being supported by local villagers in shallow waters of the mouth of the Pyin Sa Lu and Thaung Du rivers in Myanmar. Note the tusk emerging from the middle of the lower jaw, where the white coloration turns to black, extending backwards and over the top of the upper jaw. waters of the southern hemisphere between $35^{\circ}$ and $60^{\circ} \mathrm{S}$ (Jefferson et al., 2008). There is strong seasonality of strandings in the northern extent of their distribution during the late summer and autumn, which combined with the presence of sub-Antarctic squid species in the stomachs of whales stranded along the South African coast, suggests they make seasonal migrations within their range (Sekiguchi et al., 1996; Ross et al., 1998).

The stranding of a strap-toothed beaked whale in Myanmar is by far the northernmost record of the species. As mentioned above, the normal distributional limit of these whales is considered to be $35^{\circ} \mathrm{S}$ of the equator; although there exists at least one record of a stranding of an emaciated strap-toothed beaked whale farther north at about $13^{\circ} \mathrm{S}$ on Maré Island off north-eastern Brazil (Maia-Nogueira \& Nunes, 2005). The Myanmar stranding occurred more than $5000 \mathrm{~km}$ north of the species' normal distribution and more than $3000 \mathrm{~km}$ north of its previous most northerly record in north-eastern Brazil. Although the stomach of the straptoothed whale that stranded in Myanmar was empty, its robust body condition indicates that it had probably been feeding far outside of the species' normal distribution.

With intensifying cetacean research in the world's oceans, some strandings of mesoplodonts, previously thought to have been extra-limital, are now known to have occurred within the normal distribution for their species. For instance, Santos et al. (2003) speculated that a standing of Gervais' beaked whale Mesoplodon europaeus in south-eastern Brazil may have been an extra-limital record, since at the time the normal 
distribution of this species was thought to generally be limited to the North Atlantic with a only a few records recorded from south of the equator at Ascension Island (Mead, 1989). The record in south-eastern Brazil is now considered to be within the normal range of Gervais' beaked whales (see Jefferson et al., 2008). On the other hand, extreme extralimital records have been recorded for other Mesoplodon species. The normal distribution of the Gray's beaked whale Mesoplodon grayi is similar to the strap-toothed beaked whale in the southern hemisphere, but there is a confirmed record of the species from The Netherlands in the North Atlantic (Boschma, 1950, as cited in Mead, 1989). Although not as extreme as the anomalous record of a Gray's beaked whale off The Netherlands, there is a record of a Sowerby's beaked whale Mesoplodon bidens that stranded in warm waters of the Gulf of Mexico along the coast of Florida (Bonde \& O'Shea, 1989), while the normal range of this species is limited to cold waters of the North Atlantic (Jefferson et al., 2008). Considering the relatively well known range of strap-toothed beaked whales and the relatively large number of strandings-the species has the most distributional records of any mesoplodont (Mead, 1989) we consider the stranding in Myanmar to be an anomalous event rather than an extension of the normal distribution of this species.

\section{ACKNDWLEDGEMENTS}

We are grateful to $U$ Khin Ko Lay, Director General, Department of Fisheries, for providing permission to collect the carcass in Pyin Sa Lu; U Tun Win Aung, Fisheries Officer, Department of Fisheries, Pyin Sa Lu, for organizing field logistics and providing information about the stranding; and U Than Myint, Director, Wildlife Conservation Society, Myanmar Program, for his support and help in gathering information on the stranding.

\section{REFERENCES}

Bonde R.K. and O'Shea T.J. (1989) Sowerby's beaked whale (Mesoplodon bidens) in the Gulf of Mexico. Journal of Mammology 70, 447-449.
Boschma H. (1950) Maxillary teeth in specimens of Hyperodon rostralis (Müller) and Mesoplodon grayi (von Haast) stranded on the Dutch coasts. Koniklijke Nederlandse Akademie Wetenschappen Proceedings $53,3-14$.

Carlström J., Denkinger J., Feddersen P. and Øien N. (1997) Record of a new northern range of Sowerby's beaked whale (Mesoplodon bidens). Polar Biology 17, 459-461.

Jefferson T.A., Webber M.A. and Pitman R.L. (2008) Marine mammals of the world: a comprehensive guide to their identification. London: Academic Press.

Maia-Nogueira R. and Nunes J.A.C. (2005) Record of Layard's beaked whale, Mesoplodon layardii (Gray, 1856), in northeastern Brazil. Latin American Journal of Aquatic Mammals 4, 137-139.

Mead J.G. (1989) Beaked whales of the genus Mesoplodon. In Ridgeway S.M. and Harrison R. (eds) Handbook of marine mammals. Volume 6. London: Academic Press, pp. 349-329.

Pitman R.L. and Lynn M.S. (2001) Biological observations of an unidentified mesoplodont whale in the eastern tropical Pacific and probable identity: Mesoplodon peruvianus. Marine Mammal Science 17, 646657.

Ross G.J.B., Baker A.N., Goodall R.N.P., Lichter A.A. and Mead J.G. (1998) The distribution of beaked whales in the Southern Hemisphere. (Paper submitted to the Scientific Committee of the International Whaling Commission), SC/40.SM23.

Santos M.C.O., Zampirolli E., Castro A.F.V. and Alvarenga F.S. (2003) A Gervais' beaked whale (Mesoplodon europaeus) washed ashore in southeastern Brazil: extra limital record? Aquatic Mammals 29, 404-410.

and

Sekiguchi K., Klages N.T.W. and Best P.B. (1996) The diet of straptoothed whales (Mesoplodon layardii). Journal of Zoology 239, 453463.

\section{Correspondence should be addressed to:}

B.D. Smith

Ocean Giants Program

Wildlife Conservation Society

2300 Southern Boulevard,

Bronx New York 10460, USA

email: bsmith@wcs.org 